

\title{
INFLUENCE OF FLOW FIELD PATH DESIGN OF DIRECT METHANOL FUEL CELL ON "WATER FLOODING PHENOMENON" OF CATHODE
}

\author{
Qingran Meng, Aihua Tian* \\ Jilin Institute of Chemical Technology, Chengde Street, Jilin City, China \\ *Corresponding Author E-mail: tah0077@163.com
}

This is an open access article distributed under the Creative Commons Attribution License, which permits unrestricted use, distribution, and reproduction in any medium, provided the original work is properly cited

\section{ARTICLE DETAILS}

Article History:

Received 26 June 2018 Accepted 2 July 2018

Available online 1 August 2018

\section{ABSTRACT}

\begin{abstract}
The flow field directs the reactant in and the product out of direct methanol fuel cell (DMFC) through a channel system. The design of the flow field path determines the flow in the internal flow field, thus affecting the performance of the fuel cell as well as the long-term stability. In this paper, parallel channels, serpentine channels, parallel serpentine channels, interdigitated channels, spiral flow channel, mesh flow field and other innovative channels are introduced. The advantages and disadvantages of various flow paths are analyzed, and the influence of flow field parameters, such as size, pressure and cross section shape of flow path, on performance of DMFC is discussed. The advantages of the new flow field are prospected as well.
\end{abstract}

\section{KEYWORDS}

direct methanol fuel cell, flow channel, water flooding phenomenon.

\begin{abstract}
1. INTRODUCTION
Direct methanol fuel cell (DMFC) is a new generation of proton exchange membrane fuel cell (PEMFC) using methanol as fuel. Methanol is safe, reliable, easy to store and transport, convenient supply, furthermore, it has a compact structure, less costs and improved reliability compared with other fuel cells. Therefore, more and more research focus on the direct methanol fuel cell [1]. Research on direct methanol fuel cell in China started a little late. Dalian institute of chemical physics, Chinese academy of sciences, has launched an experimental demonstration prototype of direct methanol fuel cells for small fans, PDA, toy cars and mobile phones [2]. The institute also used physical gas deposition to deposit metal composite layer on the surface of silicon wafer as a fluid collector, effectively reducing the internal resistance of fuel cell. Microelectronics research institute of Tsinghua university conducted an in-depth study on micro-fuel cell based on porous silicon [3]. Shanghai institute of microsystems and information technology of Chinese academy of sciences has also made progress in research of cell structure, packaging and system integration of micro-fuel cells.
\end{abstract}

The electrochemical reaction at the cathode of the direct methanol fuel cell is oxidizer (oxygen) reacts with hydrogen ion to form water under the action of cathode catalyst. According to a research, hydrogen ions are transferred from the anode to the cathode through the proton exchange membrane, while electrons are transferred from the external circuit to the cathode [4]. The cathode reaction is

$$
3 / 2 \mathrm{O}_{2}+6 \mathrm{H}^{+}+6 \mathrm{e}^{-} \rightarrow 3 \mathrm{H}_{2} \mathrm{O}
$$

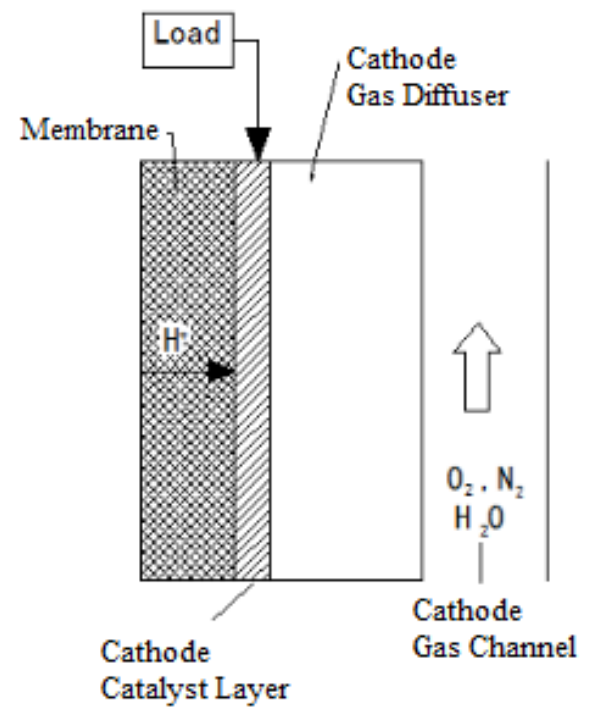

Figure 1: Diagram of cathode area of direct methanol fuel cell

The product of the cathode is water. Water flooding phenomenon happened when water accumulated in the cathode because of low flow rate of drainage. Water may clog pores in porous diffusion layer and cathode flow channel, which cause a serious impediment on transmission of $\mathrm{O}_{2}$ in the cathode. Based on a study, short supply of $\mathrm{O}_{2}$ decreased the output of the fuel cell, which resulting in poor performance of cell [5]. This paper analyzes the influence of different type of flow field channel of cell on water blockage and predicts the advantages of the new flow field path.

\section{WATER FLOODING PHENOMENON}

As the product of the cell reaction, water is mainly concentrated in the cathode. So, the researches of the cell water management focus on the researches of the cathode water management.

In cathode area, lots of water produced due to the electrochemical 
reaction, if the rate of water flow that out from cathode is too slow, liquid water will be gathered on the cathode, i.e. water flooding, which greatly increased the mass transfer resistance of oxygen, reduced the voltage of the cell. Therefore, improving the drainage ability of the cathode plays an important part in DMFC research [6]. Design of cathode channel has great influence on water management.

\section{INFLUENCE OF FLOW FIELD ON WATER FLOODING PHENOMENON}

\subsection{Basic Form of Flow Field}

The basic form of flow field channel includes serpentine channel, parallel channels, parallel serpentine channels, interdigitated channels, spiral channels and mesh flow field etc.

\section{(1) Serpentine channel}

Based on a research, serpentine channel is the most common type of channel as shown in figure 2 [7]. It is also the channel type being most widely studied. Since there is only one channel, its outstanding advantage is that it can quickly discharge the water generated by the reaction in the cell without the blockage of the water. However, for a plate with a large area, this form of flow field will cause a serious pressure to drop and an uneven distribution of current density because of a long flow path.

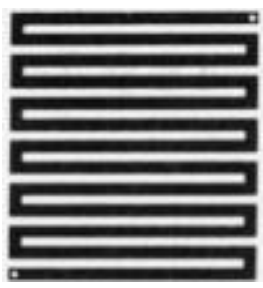

Figure 2: Serpentine channel

(2) Parallel channels

According to a research, the initial design of the parallel channel was to reduce pressure and improve efficiency, as shown in Figure 3 [8]. However, in this kind of flow field, the water was so easy to aggregate that small water droplets grow up into a large water droplet which would block some channels. In addition, slow flow rate and even no flow fluid occur in some flow field because of unreasonable design, which result in insufficient electrode reaction and poor performance of the cell.

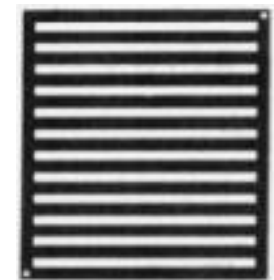

Figure 3: Parallel channels

\section{(3) Parallel serpentine channels}

Parallel serpentine channels are shown in figure 4. It can be considered as a combination of serpentine channel and parallel channel. On the other hand, serpentine channel and parallel channel are two special cases of parallel serpentine channel. According to a study, the design of parallel serpentine channel covers two special cases of serpentine channel and parallel channel. This kind of flow field path has great flexibility, its number, length and the size of flow channel can be adjusted, therefore, various suitable types channels can be designed for different applications.

\section{(4) Interdigitated channels}

According to a research, interdigitated channels, also known as discontinuous flow channels, is a kind of flow field which can greatly improve the power density of the cell, as shown in figure $5[9,10]$. A researcher stated that with all fluids pass through the diffusion layer, the water generated can be carried away completely. So, the interdigitated channels have an excellent drainage capacity [11-14]. However, the cross channel is prone to short circuit or groove flow in the case of poor design, thus reduces the utilization of reactants and electrodes.

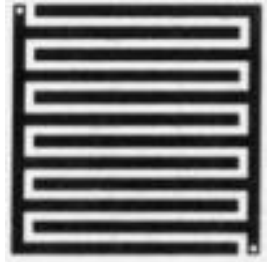

Figure 5: Interdigitated channels

(5) Spiral channels

As shown in figure 6, the spiral channels are similar to that of serpentine channel and has a good drainage capacity. However, the cross arrangement of the spiral channels near the inlet and the outlet makes the reaction gas and water concentration more evenly distributed on the whole flow field. Based on a study, this is the advantage that serpentine channel does not have [15].

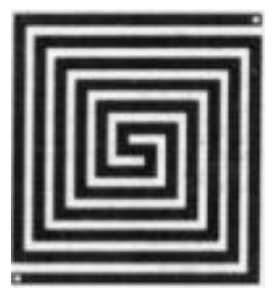

Figure 6: Spiral channels

(6) Mesh flow field

Mesh flow field, as shown in figure 7, is a kind of flow field without channel. According to a research, usually the barrier is regularly arranged between the inlet and outlet of the fluid, allowing the fluid to flow around in the pores between the barrier [16]. This kind of flow path design is more flexible, because the flow rate in this kind of flow field is relatively low, the drainage capacity is poor, but the moisture capacity is relatively good.

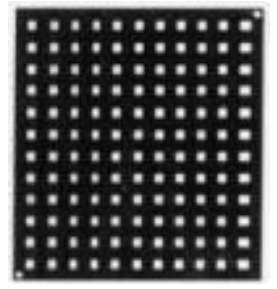

Figure 7: Mesh flow field

According to the description of the above basic forms of flow paths, the following table is summarized to compare various flow paths, as shown in table 1.

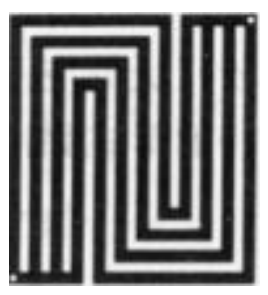

Figure 4: Parallel serpentine channels 
Table 1: Advantages and disadvantages of different flow fields

\begin{tabular}{|c|c|c|c|c|c|c|}
\hline type & $\begin{array}{l}\text { serpentine } \\
\text { channel }\end{array}$ & $\begin{array}{l}\text { parallel } \\
\text { channels }\end{array}$ & $\begin{array}{l}\text { parallel } \\
\text { serpentine } \\
\text { channels }\end{array}$ & $\begin{array}{l}\text { interdigitated } \\
\text { channels }\end{array}$ & $\begin{array}{l}\text { spiral } \\
\text { channels }\end{array}$ & $\begin{array}{l}\text { mesh flow } \\
\text { field }\end{array}$ \\
\hline $\begin{array}{l}\text { advant } \\
\text { ages }\end{array}$ & $\begin{array}{l}\text { Quickly drain } \\
\text { the water } \\
\text { generated by } \\
\text { the reaction in } \\
\text { the cell } \\
\text { without } \\
\text { blockage of } \\
\text { the channel } \\
\text { water. }\end{array}$ & $\begin{array}{l}\text { Reduce } \\
\text { pressure } \\
\text { and } \\
\text { improve } \\
\text { efficiency. }\end{array}$ & $\begin{array}{l}\text { With great } \\
\text { flexibility, the } \\
\text { number, the } \\
\text { length and the } \\
\text { size of the } \\
\text { channel can be } \\
\text { adjusted. }\end{array}$ & $\begin{array}{l}\text { Improved cell } \\
\text { power density, } \\
\text { excellent } \\
\text { drainage } \\
\text { capacity. }\end{array}$ & $\begin{array}{l}\text { With good } \\
\text { drainage } \\
\text { capacity, the } \\
\text { reaction gas } \\
\text { and water } \\
\text { concentratio } \\
\text { n are evenly } \\
\text { distributed. }\end{array}$ & $\begin{array}{l}\text { More } \\
\text { flexibility } \\
\text { and good } \\
\text { moisture } \\
\text { retention. }\end{array}$ \\
\hline $\begin{array}{l}\text { disadv } \\
\text { antage } \\
\text { s }\end{array}$ & $\begin{array}{l}\text { Large } \\
\text { pressure drop } \\
\text { due to the long } \\
\text { flow path. } \\
\text { Distribution of } \\
\text { current } \\
\text { density is not } \\
\text { uniform. }\end{array}$ & $\begin{array}{l}\text { Water } \\
\text { tends to } \\
\text { gather and } \\
\text { grow up. } \\
\text { Water } \\
\text { droplets } \\
\text { block flow } \\
\text { paths. }\end{array}$ & $\begin{array}{l}\text { Too much } \\
\text { water tends to } \\
\text { gather and } \\
\text { block the flow } \\
\text { paths. }\end{array}$ & $\begin{array}{l}\text { Short circuit or } \\
\text { groove flow } \\
\text { may occur in } \\
\text { the case of } \\
\text { poor design. }\end{array}$ & $\begin{array}{l}\text { Large } \\
\text { pressure } \\
\text { drop due to } \\
\text { the long flow } \\
\text { path. } \\
\text { Distribution } \\
\text { of current } \\
\text { density is } \\
\text { not uniform. }\end{array}$ & $\begin{array}{l}\text { Poor } \\
\text { drainage } \\
\text { capacity. }\end{array}$ \\
\hline
\end{tabular}

It can be seen from table 1 that serpentine channel, interdigitated channels, and spiral channels have good drainage capacity. And the water of parallel channels tends to aggregate without flow due to the low pressure in the channels. Parallel serpentine channels combine the advantages and disadvantages of the parallel flow field and serpentine flow field, in which there are too much water gathered and block the flow channels because of the long path. The mesh flow field presents good moisturizing effect but low drainage capacity.

\subsection{Innovative Design of Flow Field}

(1) Bionic flow field

In order to improve the uniformity of fluid distribution, the designers have come up with a lot of innovative designs, e.g. Tüber put forward a flow field form named shunt channels, as shown in figure 8. This kind of flow field can improve the uniformity of fluid distribution and reduce the energy consumption to a great extent. The flow field adopts the bionics principle to make the fluid flow in the "smooth" pipe, thus reducing the pressure drop of the flow, at the same time, the fluid of each branch can be distributed uniformly through computer design.
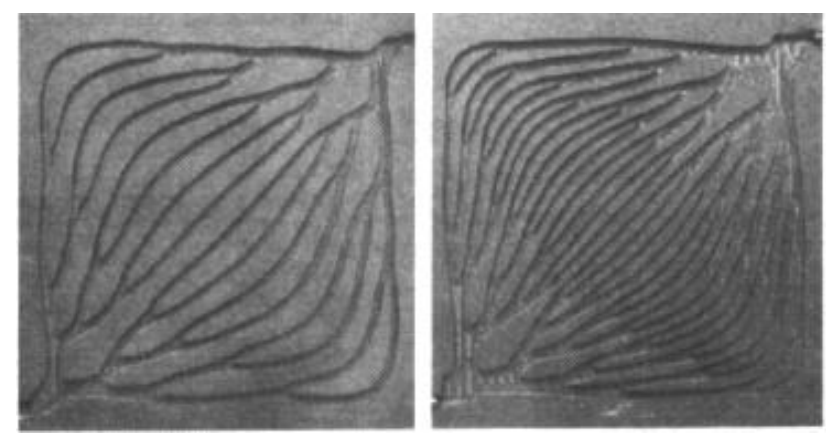

Figure 8: Schematic diagram of shunt channels

(2) Gradient channels

Usually the concentration of reactant reduces along with the direction of fluid flow. In order to solve this problem a researcher invented a new type of flow field, as shown in figure 9. The character of this type of flow field is gradually reduced cross-sectional area of the liquid flow channel. The thinner the channels, the higher the flow rate, thus compensates for the reduced concentration of reactants.

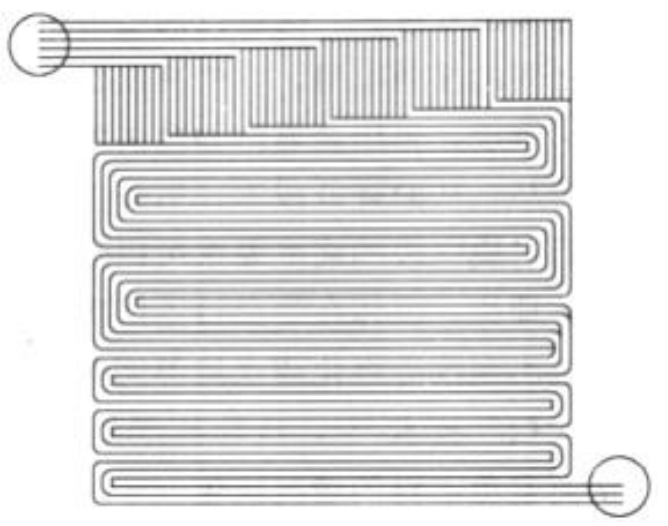

Figure 9: Schematic diagram of gradient channels

\section{PROSPECT OF FLOW FIELD RESEARCH}

It is regarded that the hydrogen energy is suitable for present situation of China. As one kind of the hydrogen energy, direct methanol fuel cell presents many attractive characters. It is a highly efficient clean energy without reforming. At the end of 2015, fuel cell power system was mentioned again in the key layout of the 13th five-year plan of the ministry of science and technology [17].

Many progresses have been obtained in the research of DMFC. E.g. Daimler-chrysler Company of U.S. developed a fuel cell car named NECAR5 which has completed a 3,000-mile test run. Changchun institute of applied Chemistry Chinese academy of sciences has developed China's first 100 watt direct methanol fuel cell reactor and successfully applied it to electric bicycles [18]. In the near future, direct methanol fuel cell will make greater contribution for new energy sources. As an important part of the cell, the flow field of the direct methanol fuel cell is expected to make a breakthrough in the following research.

\section{CONCLUSIONS}

The following conclusions are drawn from the analysis of the design forms of the cathode channels of direct methanol fuel cell. The size of the flow channels should be reasonable, the length should not be too long, otherwise the water in the flow channels would gather and block the flow channels; The pressure in the flow channels should be distributed evenly. Low pressure will cause water accumulation and block the flow channels. Gradually reduced cross-sectional area of the liquid flow channel can increase the fluid flow rate, which substantially compensate the reduced concentration of reactant as fluid flow along the channels. It can eliminate the blocking flow to some extend as well. 


\section{REFERENCES}

[1] Li, Y., Wang, Y.S. 2000. Fuel cell. Beijing: Metallurgical engineering press.

[2] Liu, J.G., Yi, B.L., Wei, Z.B. 2001.The principle of direct methanol fuel cell, progress and main technical problems. Journal of Power technology, 1, (5) 363-363.

[3] Huang, H.L., Sui, J., Chen, H.Y., Li, W.S. 2004. Research progress of direct methanol fuel cell at home and abroad. Journal of Battery Industry, 1, (06) 320-324.

[4] Guo, H., Ma, C.F., Wang, M.H. 2003. Heat and Mass Transfer and TwoPhase Flow in Hydrogen Proton Exchange Membrane Fuel Cells and Direct Methanol Fuel Cells. Proceedings of First International Conference on Fuel Cell Science, Engineering and Technology.

[5] Ye, F., Xu, R., Guo, H., Ma, C.F., Wang, M.H. 2006. Direct methanol fuel cell membrane and cathode simulation Journal of Engineering Thermal Physics, 1 (6), 1017-1019.

[6] Jiang, J.H., Gong, L., Li, Y.S. 2017. Transport characteristics of cathode water from direct methanol fuel cell. Chemical Journal, 68, (S1), 83-89.

[7] Wilson, D.S. 1997. Fuel cell fluid flow field plate. US Patent.

[8] Mao, Z.Q. 2005. Fuel cell. Beijing, chemical industry press.

[9] Wilson, M.S. 1997. Fuel cell with interdigitated porous flow-field. US
Patent.

[10] Wilson, M.S. 1998. Fuel cell with interdigitated porous flow-field. Journal of Power Sources,70 (2).

[11] Yi, B.L. 2000. Fuel cell: university, environment-friendly power generation. Beijing, chemical industry press.

[12] Tüber, K., Oedegaard, A., Hermann, M., Hebling, C. 2003. Investigation of fractal flow-fields in portable proton exchange membrane and direct methanol fuel cells. Journal of Power Sources, 131(1).

[13] Zhong, J.L. 1999. Fuel cell containing gas guide plate. Chinese patent.

[14] Hou, M., Yi, B.L. 2012. Development status and prospect of fuel cell technology. Journal of Electrochemistry, 18, (01) 1-13.

[15] Sun, H., Gao, Z.G., Lei, D., Nie, M. 2017. Research and development prospects of direct alcohol fuel cell. Journal of Vacuum, 54, (04), 64-68.

[16] Cho, T.J. 2017. Innovative Micro-Dust Reduction Technologies. Acta Chemica Malaysia, 1, (1), 04-07.

[17] Aldaihani, N., Alenezi, R. 2017. Estimation of CO2 Emissions of The Vehicles Transport Sector in The State of Kuwait. Acta Chemica Malaysia, $1,(1), 08-12$.

[18] Marlia M. Hanafiah, Mohamed Yasreen M. Ali, Nur Izzah Hamna A. Aziz, Akbar John. 2017. Biogas Production from Agrowaste And Effluents. Acta Chemica Malaysia, 1, (1), 13-15. 